Elżbieta DACZKOWSKA-KOZON

Fish microbiology

\title{
EFFECT OF FISHING SEASON ON TOTAL COUNT OF COLD-TOLERANT MICROBES ON ICED BALTIC HERRING
}

\section{WPEYW OKRESU POEOWU NA LICZEBNOŚĆ MIKROFLORY ZIMNOLUBNEJ NA LODOWANYM ŚLEDZIU BAETYCKIM}

\author{
Department of Fish Quality Control \\ Academy of Agriculture, Szczecin
}

\begin{abstract}
It was noted for the fishing season to effect the initial number of psychrophilic and psychrotrophic bacteria on the skin and within intestines of the Baltic herring. Number of proteolytic and lipolytic strains in the total count of cold tolerant bacteria was inversly proportional, both, for type of the sample tested and the fishing season.

The multiplication rate was fastest and time for cold tolerant microbes to enter the Baltic herring's tissue, while stored in ice at $+4 \mathrm{C}$, shorter for the fish caught in the spawning season.
\end{abstract}

\section{INTRODUCTION}

A newly caught, healthy fish has aseptic tissue and numbers of microorganisms present on outer and inner surfaces can vary within a high range (Huss, 1988; Larsen et al. 1978, Shewan and Murray, 1979). Differences in quantitative and qualitative composition of microflora depends, mostly, on environmental conditions and, when it comes to intestines, on feeding habits of the fish, as well. Newertheless, there is an evidence for the above mentioned factors to have no effect on numbers of microbes present on fish (Shewan, 1977).

The aim of this work was to find out if fishing season affects numbers of cold tolerant microbes present on the Baltic herring, both as total and when divided into groups of activities essential for the fish quality, and wheather time of capture affects quantitative changes in cold tolerant microflora on iced herring under cold storage. 


\section{MATERIAL AND METHODS}

Subject of the surveys were skin, intestines and tissue of the Baltic herring caught in the Pomeranian Bay. For details see Table 1.

Table 1

Characteristic of the Baltic herring tested

\begin{tabular}{|c|c|c|c|}
\hline Batch no. & Date of catch & & $\begin{array}{l}\text { Gonad's maturity according } \\
\text { to Mair's scale } \\
\text { (Kołakowska et al., 1992) }\end{array}$ \\
\hline 1 & 14.03 .90 & pre-spawning & V \\
\hline 2 & 26.03 .90 & pre-spawning & V \\
\hline 3 & 29.03 .89 & pre-spawning & V \\
\hline 4 & 11.04 .89 & spawning & VI \\
\hline 5 & 08.06 .89 & post-spawning & VIII \\
\hline
\end{tabular}

The Baltic herring, when delivered in ice to the laboratory, was kept under refrigerated temperature $(+4 \mathrm{C})$.

Fish individuals, collected at random (three fish for each analysis) were tested immediately after delivery in ice (up to 3 hours after catch) and after 2.5 and 8 days of cold storage in ice.

Microbiological analysis included:

1. Estimation of total viable count (TVC) of psychrotrophic and psychrophilic bacteria per $1 \mathrm{~cm}^{2}$ of skin or $1 \mathrm{~g}$ of intestines and tissue on the Frazier's medium.

2. Estimation of TVC of proteolytic (P), lipolytic (L) and $\mathrm{H}_{2} \mathrm{~S}$ producing bacteria

$\mathrm{H}_{2} \mathrm{~S}$ on Frazier's medium, Nutrient agar + Tween 80 (NAT) and LAA medium, respectively.

Aseptically collected samples, when homogenized with $0.1 \%$ buffered peptone wa. ter, were decimally diluted and then spreaded onto surface of appropriate medium. Plates were incubated at $20^{\circ} \mathrm{C}$ for 5 days and the grown up colonies counted.

As to give numbers of proteolytic bacteria, Frazier's reagent was used and the colonies with a transparent zone around counted. Lipolytic strains were identified by precipitation zone around the colonies on NAT medium while gray to black colonies on the LAA medium were typical for the $\mathrm{H}_{2} \mathrm{~S}$ producers and as such counted as well. 
Presented results are geometric mean of three repetitions done for each three individuals taken for each analysis.

\section{RESULTS AND DISCUSSION}

Domination of the temperate water fish microflora with psychrophilic and psychrotrophic bacteria causes the quantitative and qualitative composition of this group to influence directly the quality and shelf-life of fish raw material.

Analysis conducted on skin and intestine samples of the Baltic herring from various fishing seasons proved there to be a relation between the total count of cold tolerant microbes and the fishing period (Fig. 1).

Number of cold tolerant microbes ranged from $10^{3}-10^{4} \mathrm{JTK} / \mathrm{cm}^{2}$ of skin or $1 \mathrm{~g}$ of intestine during the pre-spawning season and increased, in both environments tested, by 1 to 2 orders of magnitude, in value, in post-spawning fish. The differences being more clear in the intestine samples proved there to be a direct relation between the feeding intesity and the total count of microbes within intestines of the Baltic herring.

Relations between the percentage share of proteolytic, lipolytic and $\mathrm{H}_{2} \mathrm{~S}$ producing strains in total count of the cold tolerant microbes on skin and within the intestines of herring were inversly proportional in the two fishing periods under comparison (Tab. 2).

Percentage share proteolytic (P), lypolitic (L) and $\mathrm{H}_{2} \mathrm{~S}$ producing bacteria $\left(\mathrm{H}_{2} \mathrm{~S}\right)$

Table 2 in total count of cold tolerant microbes on fresh, iced Baltic herring

\begin{tabular}{|c|c|c|c|c|c|c|}
\hline \multirow{2}{*}{$\begin{array}{c}\text { Date of } \\
\text { catch }\end{array}$} & \multicolumn{3}{|c|}{ Skin } & \multicolumn{3}{c|}{ Intestines } \\
\cline { 2 - 6 } & $\mathrm{P}$ & $\mathrm{L}$ & $\mathrm{H}_{2} \mathrm{~S}$ & $\mathrm{P}$ & $\mathrm{L}$ & $\mathrm{H}_{2} \mathrm{~S}$ \\
\hline 08.06 .89 & 30.3 & 15.5 & 11.0 & 98.7 & 41.9 & 97.5 \\
14.03 .90 & 82.0 & 55.6 & 1.8 & 29.1 & 16.1 & 6.1 \\
26.03 .90 & 57.7 & 24.3 & 18.6 & 8.2 & 9.7 & 23.8 \\
\hline
\end{tabular}

For the post-spawning herring, for example, almost $100 \%$ of cold tolerant microbes present within intestines were proteolytic and $\mathrm{H}_{2} \mathrm{~S}$ producing strains, while for the skin from the same time of capture their share in total count were equal 30.3 and $11.0 \%$, respectively. Percentage share of all the tested groups of activity in total count of cold tolerant microbes, within the spawning fish intestines, has not exceeded $30 \%$. 


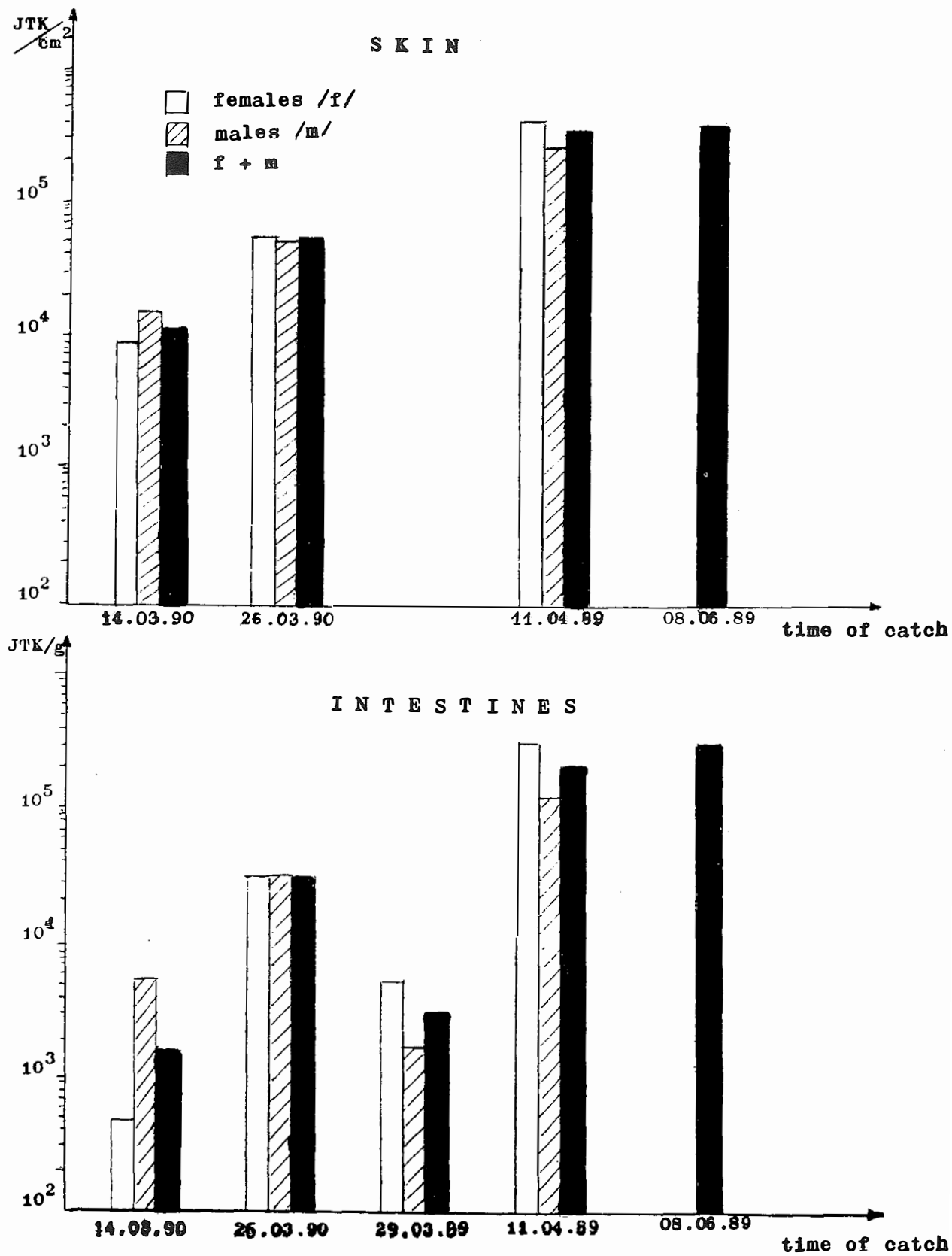

Fig. 1. Effect of fishing season on total count of cold tolerant bacteria on skin and in the intestines of the Baltic herring 
Increased percentage share of proteolytic and lipolytic strains in the total count for the skin of fish from the same catch period may be explained either by decrease or disappearence of antibacterial activity of the slime ingredients in the spawning individuals and low-molecular protein and fatty acid compounds present within the slime, on the skin and diffusing there from fish tissues being easy available nutritive compound for the above mentioned groups of activity (Larsen et al., 1978).

Effect of the fishing period is also visible when testing changes in total counts of cold tolerant microbes of the Baltic herring under its refrigerated storage in ice (Fig. 2).

In most cases logaritmic increase in number of cold tolerant microbes differed slightly due to the time of fish capture. Although lower, when compared with the feeding fish, the total count of microbes, both on the skin and within intestines of spawning fish, was increasing more rapidly under cold storage of fish.

An intensive increase in number of aerobic bacteria - a dominating group within the Gram-negative cold tolerant microbes - in the herring intestines, when stored in cold is, probably, due to possible usage by this group, as a final acceptor of electrones in case of an oxygen defficiency, the TMAO, present in marine fish, in high quantities (Huss, 1988).

A faster growth of cold tolerant microbes on fish caught in the pre-spawning period was accompanied by faster appearence of these bacteria in tissue of fish under cold storage (Fig. 2). It could be caused either by a greater permeability of natural bariers or by disappearence or decreasing efficiency of factors avoiding penetration of bacteria into the tissue of individuals weakened by spawning activity. Faster appearence of bacteria in the tissue was accompanied by their faster multiplication in this environment, under cold storage, when compared to changes in microbial count in tissue of pre-spawning herring under the same storage conditions.

Despite the differences in microbiological quality of the herring tissue from the fishing periods under comparison, on the 8th day of cold storage the total count of cold tolerant microbes has not exceeded $5,0 \times 10^{5} \mathrm{JTK} / \mathrm{g}$.

The qualitative microbiological analysis conducted under cold storage of herring caught in the feeding period proved there to be essential differences in the percentage share of strains representing various groups of activity in the total count of cold tolerant microbes on skin and in the intestines. When it comes to the tissue under cold storage the fastest increase, expresed by the percentage in total count, was noted for the lipolytic strains (Fig. 3). It resulted possibly, from the high content of lipids in the herring tissue due to its intensive feeding on mesoplancton during the postspawning period (Kołakowska et al., 1992).

The total count of cold tolerant microbes on skin of the Baltic herring, under cold storage, reached level of $10^{6}$ to $10^{7} \mathrm{JTK} / \mathrm{cm}^{2}$ between 2 and 5 th day of storage. 

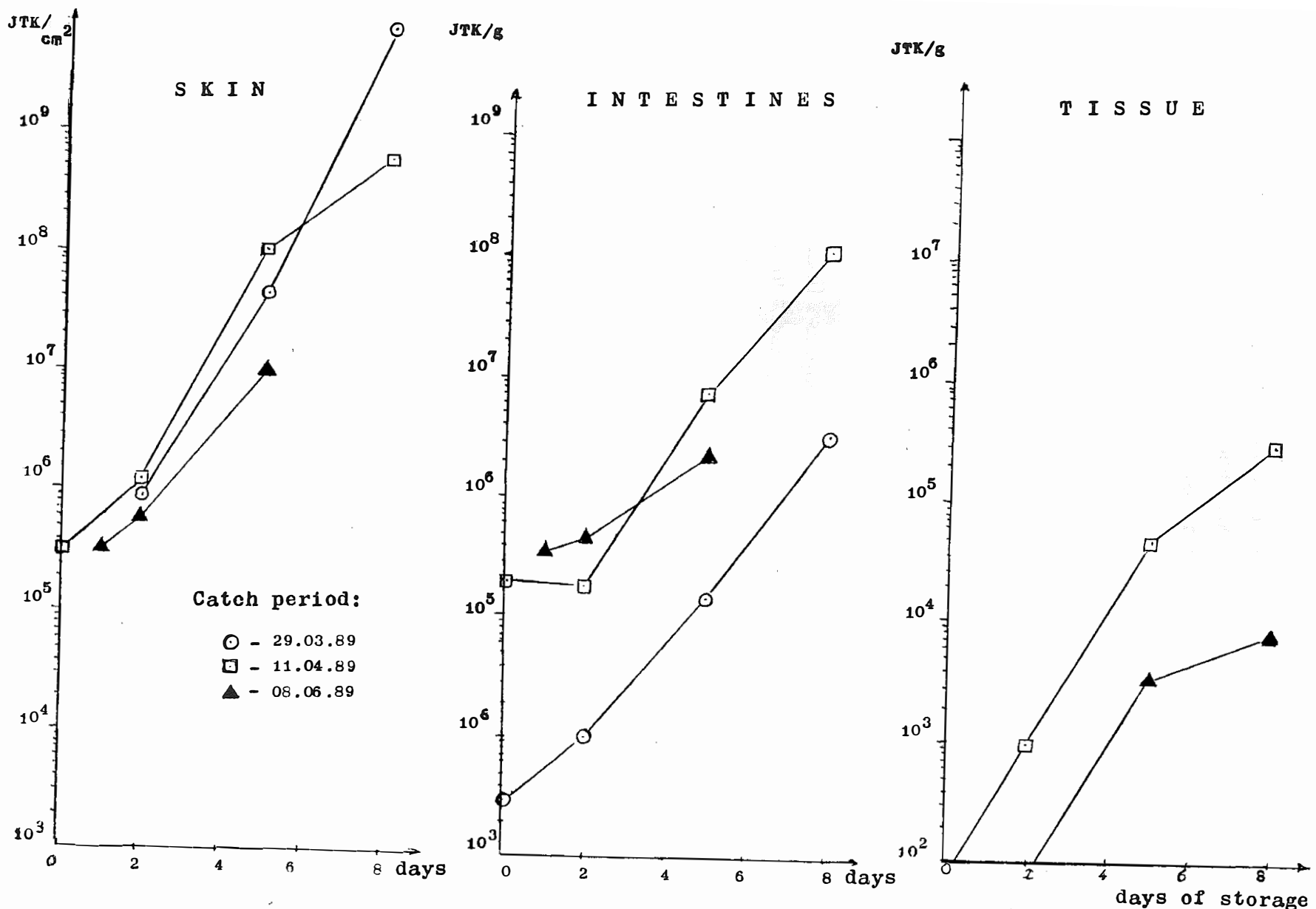

Fig. 2. Effect of cold storage $\left(+4^{\circ} \mathrm{C}\right)$ on changes in total count of cold tolerant microbes on skin and in the intestines of the Baltic herring from various catch periods 
\begin{tabular}{lllllllllll}
0 & 10 & 20 & 30 & 40 & 50 & 60 & 70 & 80 & 90 & $100 \%$ \\
\hline
\end{tabular}

0

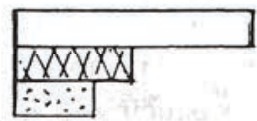

$2 \frac{}{x y}$

5

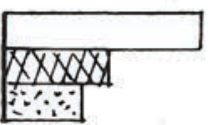

$\square P$

L

$\mathrm{B}_{2} \mathrm{~S}$

0

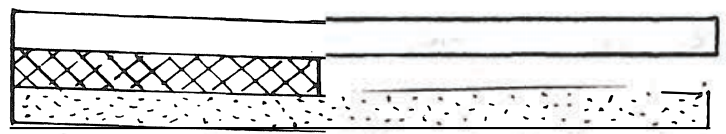

2

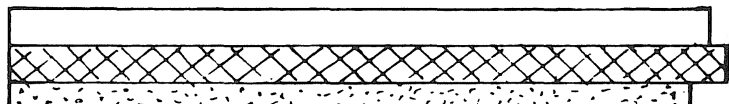

I N T E S T I N E S

5

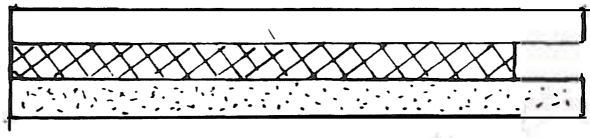

0

|

2

1

5

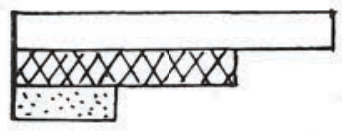

T I S S U E

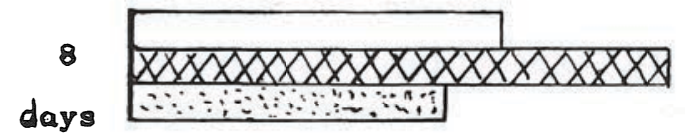

$\begin{array}{llllllllllll}0 & 10 & 20 & 30 & 40 & 50 & 60 & 70 & 80 & 90 & 100 & 1\end{array}$

Fig. 3. Effect of cold storage $\left(+4^{\circ} \mathrm{C}\right)$ on percentage share of proteolytic $(\mathrm{P})$, lipolytic $(\mathrm{L})$ and $\mathrm{H}_{2} \mathrm{~S}$ producing bacteria $\left(\mathrm{H}_{2} \mathrm{~S}\right)$ in total count of cold tolerant microbes on iced Baltic herring 
Reay and Shewan (Barak and Ulitzur, 1980) proved there to be a relation between organoleptic changes accompanying fish deterioration and the microbiological load of $10^{6}$ to $10^{7} \mathrm{JTK} / \mathrm{cm}^{2}$ of skin.

The total count of $10^{6}$ cold tolerant microbes $/ \mathrm{cm}^{2}$ of skin on 2 nd to 5 th day of cold storage together with high proteolytic, lipolytic and $\mathrm{H}_{2} \mathrm{~S}$ producing strains count, had to add to undesired changes in organoleptic features noted for herring from the April catches (Kołakowska et al., 1992) although the total count of cold tolerant microbes within the fish tissue, at the same time, was much below level indicatory for the spoilage process.

According to Chai et al. (Chai et al., 1969) numbers of proteolytic and $\mathrm{H}_{2} \mathrm{~S}$ producing bacteria in total count of cold tolerant microbes on the carangid fillets stored at $+1 \mathrm{C}$ increased from initial 27.4 and $3.4 \%$ to 37.5 and $34.5 \%$, respectively, on the 6-th day of cold storage.

In the tissue of ungutted herring stored at $+4 \mathrm{C}$, cold tolerant proteolytic and $\mathrm{H}_{2} \mathrm{~S}-$ producing bacteria stated for 44.7 and $14.3 \%$ of the total count, on the 5th day of cold storage, while after 8 days under the same storage conditions, were equal to 52.2 and $43.7 \%$, respectively. In both cases under comparison increase in number of $\mathrm{H}_{2} \mathrm{~S}$ - producers was clear and their role in biodegradation process of fish under cold storage undoubtful.

\section{CONCLUSSIONS}

1. The total count of cold tolerant microbes present on the skin and within intestines of iced Baltic herring is fishing season dependent.

2. Relations between numbers of proteolytic and lipolytic bacteria in the total count of cold tolerant microbes on the skin and within intestines of herring from preand post-spawning season are inversly proportional.

3. Increase in number of cold tolerant bacteria on the skin, within intestines and tissue of the herring, under cold storage, was faster for fish individuals caught in the spawning season than at the begining of intesive feeding time.

4. Penetration of cold tolerant microbes into tissue, under cold storage conditions, was somewhat faster for the spawning fish individuals than for the feeding ones.

\section{REFERENCES}

Barak Mo, S. Ulitzur, 1980: Bacterial bioluminescence as an early indicator of marine fish spoilage. European J. Appl. Microbiol. Biotechn. 10: 155-156.

Chai T., C. Chen, A. Rosen, K.E. Levin, 1969: Detection and incidence of specific species of spoilage bacteria on fish. Appl. Microbiol. 16: 1738-1791. 
Hobbs G., 1986: Ecology of food microorganisms. Microb. Ecol. 12: 15-30.

Huss H.H., 1988: Fresh fish - quality and quality changes. FAO Fish Ser. no. 29.

Kołakowska A., B. Czerniejewska-Surma, L. Gajowiecki, K. Lachowicz, Lo Zienkiewicz, 1992: Effect of fishing season of shelf life of iced Baltic herring. In Quality assurance in the fish industry. eds. H.H. Huss et al. Elsevier Science Publ.: 81-91.

Larsen J.L., N.C. Jensen, N.O. Christensen, 1978: Water pollution and the ulcer-syndrome in the cod (Gadus morhua). Vet. Sci. Commun. 2: 207-216.

Shewan J.M., 1977: The bacteriology of fresh and spoiling fish and the biochemical changes induced by bacterial action. In Handling, processing and marketing of tropical fish. Tropical Products Inst., 51.

Shewan J.Mo, C.K. Murray, 1979: The microbial spoilage of fish with special reference to the role of psychrophiles. 1. Cold tolerant microbes in spoilage and the environment. ed. A.D. Russel and P. Fuller, Academic Press: 117-136.

Elżbieta DACZKOWSKA-KOZON

\section{WPEYW OKRESU POŁOWU NA LICZEBNOŚĆ MIKROFLORY ZIMNOLUBNEJ NA LODOWANYM ŚLEDZIU BAETYCKIM}

\section{STRESZCZENIE}

Analiza mikrobiologiczna śledzi bałtyckich potwierdziła wpływ okresu połowu tak na wyjściową liczebność bakterii psychrofilnych i psychrotrofowych na skórze i w przewodzie pokarmowym śledzia, jak i na szybkość ich namnażania się i przenikania do tkanki w trakcie składowania chłodniczego ryb w lodzie.

Udział szczepów proteolitycznych i lipolitycznych w ogólnej liczbie bakterii zimnolubnych na skórze i w przewodzie pokarmowym śledzi z połowów przed i potarłowych charakteryzowała odwrotnie proporcjonalna zależność. Szczepy proteolityczne np. dominowały w ogólnej liczbie bakterii zimnolubnych na skórze śledzi złowionych $\mathrm{w}$ okresie przedtarłowym przy znikomym udziale procentowym tej grupy w przewodach pokarmowych ryb z tego samego okresu. Odwrotne relacje stwierdzono dla śledzi z połowów potarłowych.

Author's address:

Received: 1993.05 .25

Dr Elżbieta Daczkowska-Kozon

Pracownia Mikrobiologii Żywności

Akademia Rolnicza

ul. K. Królewicza 4

71-550 Szczecin

Polska (Poland) 